OPEN ACCESS

Edited by:

Lea Atanasova,

University of Natural Resources and

Life Sciences Vienna, Austria

Reviewed by:

Weaam Ebrahim,

Mansoura University, Egypt Mariana Guilger-Casagrande, Instituto de Ciência e Tecnologia

(Unesp), Sorocaba, Brazil Jaka Razinger,

Agricultural Institute of Slovenia, Slovenia

*Correspondence: Claudia A. Ramírez-Valdespino claudia.ramirez@cimav.edu.mx

Specialty section:

This article was submitted to Fungi-Plant Interactions,

a section of the journal

Frontiers in Fungal Biology

Received: 25 August 2021 Accepted: 28 October 2021 Published: 01 December 2021

Citation:

Ramírez-Valdespino CA and Orrantia-Borunda E (2021) Trichoderma and Nanotechnology in Sustainable Agriculture: A Review.

Front. Fungal Biol. 2:764675 doi: 10.3389/ffunb.2021.764675

\section{Trichoderma and Nanotechnology in Sustainable Agriculture: A Review}

\author{
Claudia A. Ramírez-Valdespino * and Erasmo Orrantia-Borunda \\ Laboratorio de Nanotoxicología, Departamento de Medio Ambiente y Energía, Centro de Investigación en Materiales \\ Avanzados, Chihuahua, Mexico
}

Due to their unique properties and functionalities, nanomaterials can be found in different activities as pharmaceutics, cosmetics, medicine, and agriculture, among others. Nowadays, formulations with nano compounds exist to reduce the application of conventional pesticides and fertilizers. Among the most used are nanoparticles (NPs) of copper, zinc, or silver, which are known because of their cytotoxicity, and their accumulation can change the dynamic of microbes present in the soil. In agriculture, Trichoderma is widely utilized as a safe biocontrol strategy and to promote plant yield, making it susceptible to be in contact with nanomaterials that can interfere with its viability as well as its biocontrol and plant growth promotion effects. It is well-known that strains of Trichoderma can tolerate and uptake heavy metals in their bulk form, but it is poorly understood whether the same occurs with nanomaterials. Interestingly, Trichoderma can synthesize NPs that exhibit antimicrobial activities against various organisms of interest, including plant pathogens. In this study, we summarize the main findings regarding Trichoderma and nanotechnology, including its use to synthesize NPs and the consequence that these compounds might have in this fungus and its associations. Moreover, based on these findings we discuss whether it is feasible to develop agrochemicals that combine NPs and Trichoderma strains to generate more sustainable products or not.

\footnotetext{
Keywords: Trichoderma, nanotechnology, metal tolerance, tolerance to NPs, biosynthesis of nanoparticles, mycosynthesis of nanoparticles
}

\section{INTRODUCTION}

Currently, there is a great demand for food products in the agricultural sector, which means that the soil must contain all necessary nutrients and adequate properties for the optimal development of crops. In addition, crops are susceptible to being attacked by phytopathogens, requiring the use of agrochemicals such as fertilizers and pesticides to counteract the negative effects caused by the pathogen. Recently, the use of agrochemicals containing nanostructured materials has emerged as an alternative in agriculture (Singh et al., 2020).

Among the main nanoparticles (NPs) that have been used in agriculture, standing out are silver NPs (AgNPs), zinc oxide NPs (ZnONPs), and copper oxide NPs (CuONPs), which can be obtained by physical, chemical, and biological methods. Physical and chemical methods, such as ultraviolet radiation, aerosol technologies, lithography, laser ablation, ultrasonic fields, and photochemical reduction techniques, turn out to be expensive methods involving the use and release of toxic 
compounds during the process, which can cause environmental pollution (Narayanan and Sakthivel, 2010; Guilger-Casagrande and Lima, 2019). On the other hand, the biosynthesis of some types of metal NPs provides a simple, large-scale, economical, and environmentally friendly alternative (Vahabi et al., 2011; Mishra et al., 2014; Saravanakumar et al., 2017; Guilger-Casagrande and Lima, 2019). Moreover, it has been reported that biosynthesized NPs show lower toxicity than NPs obtained by chemical methods due to their stabilization with organic compounds and because no toxic residues are generated during the synthesis process (Fraceto et al., 2018). Furthermore, these new eco-friendly synthesis methods additionally provide better biocompatibility in the use of NPs (Guilger-Casagrande and Lima, 2019).

Biosynthesis can be carried out using plant extracts, bacteria, fungi, algae, yeasts, or bioproducts of their metabolism, including enzymes, agro-industrial residues, and microbial pigments (Gemishev et al., 2019; Elegbede et al., 2020). Similarly, it has been reported that secondary metabolites and other compounds that microorganisms release as a protective mechanism help in metal biosynthesis by converting ions into elemental metal (Vahabi and Dorcheh, 2014; Fraceto et al., 2018).

Thus, molecules released by certain organisms possessing metal resistance can act as reducing and stabilizing agents for the synthesis of metallic NPs (Guilger-Casagrande and Lima, 2019). These stabilizing or protective agents known as cappings, influence the interaction of physicochemical properties of the nanoparticle surface with its environment (Diko et al., 2020). It should be noted that the stability of the cappings depends on the $\mathrm{pH}$ : at high $\mathrm{pH}$ values, the NPs remain stable in solution, while at low $\mathrm{pH}$ values, the proteins that form the cappings denature (Pal and Hossain, 2020).

Filamentous fungi are among the microorganisms with the greatest potential for NP biosynthesis, since their use is more efficient compared with other bioalternatives due to the possibility of easy large-scale cultivation and biomass collection, their high tolerance to metals, resistance to high pressure, and agitation fluxes, as well as the high production of extracellular proteins (Narayanan and Sakthivel, 2010; Vahabi et al., 2011; Salvadori et al., 2014a; Guilger-Casagrande and Lima, 2019). Furthermore, large amounts of extracellular proteins secreted by fungi have been found to increase the synthesis of NPs (Diko et al., 2020). On the other hand, an advantage of using fungi over bacterial systems is that NPs precipitate outside the cell without cellular contaminants and can be directly used in various applications (Narayanan and Sakthivel, 2010). Thus, fungi have been positioned as agents of interest for the biosynthesis of NPs, a process called mycosynthesis. Among the main fungi used are Fusarium, Aspergillus, Penicillium, and Trichoderma (Bhainsa and D'souza, 2006; Honary et al., 2012; Shelar and Chavan, 2015; Rai et al., 2021).

Trichoderma species are widely distributed in the soil and are known to be excellent biocontrol agents and plant growth promoters (Contreras-Cornejo et al., 2009; Hermosa et al., 2012). In addition, these species have started being used in nanotechnology, mainly in the synthesis of metal NPs. More recently, their resistance to different nano compounds has been reported, but little is known about their contribution in the biosynthesis of metallic NPs by their tolerance generated to these compounds and how these affect Trichoderma associations (Banik and Luque, 2017; Luo et al., 2018). On the other hand, Trichoderma has a high tolerance to metals and it is proposed as a potential bioremediator of contaminated environments (Tripathi et al., 2013). As mentioned above, Trichoderma is one of the main fungi used for the mycosynthesis of NPs, suggesting that it may have mechanisms of tolerance to these structures, which could be used synergically to develop products that improve crop weight and treatment against phytopathogens.

Although it is known that the characteristics of bulk material are different from those of an NP, even changing the effects that these structures can have on biological systems, similar tolerance mechanisms can be proposed, helping understand how NPs would be affecting organisms. In this review, we focus on Trichoderma and the efforts that the scientific community has made to develop strategies for the biosynthesis of NPs and their effect against microbes, mainly phytopathogens, as well as the mechanisms of tolerance to the metals present in Trichoderma and their possible extrapolation to the tolerance that Trichoderma shows against NPs. Also, we discuss whether the development of products combining Trichoderma and NPs is an option for sustainable agriculture (Figure 1).

\section{TRICHODERMA AS A SYNTHESIZER OF NPS}

Trichoderma-mediated mycosynthesis of NPs can be performed by enzymes such as reductases that can act as bioreductive agents in the biofabrication of NPs (Elegbede et al., 2020). Also, the properties and characteristics of the different metallic NPs obtained suggest that Trichoderma is a controllable source of biological synthesis of NPs (Maliszewska et al., 2009; Kareem et al., 2020). In addition, enzymes, proteins, and secondary metabolites that are involved in the biological control of plant pathogens are also generated, which can provide additional biological activity and stability to the obtained NPs (Mishra et al., 2014; Vahabi and Dorcheh, 2014). NPs synthesized by Trichoderma spp. have been found to exhibit antimicrobial activity against different microorganisms, especially phytopathogens such as Fusarium, Aspergillus, Pseudomonas, and Xanthomonas (Ponmurugan, 2017; Consolo et al., 2020; Shobha et al., 2020; Bilesky-José et al., 2021; Boruah and Dutta, 2021).

It is important to consider the parameters used in mycosynthesis and the individual characteristics of the fungal strains to optimize the parameters used to achieve the good mono-dispersity, stability, and biocompatibility of the NPs (Guilger-Casagrande and Lima, 2019). For example, it has been reported that the main factors controlling the nucleation and subsequent formation of metallic NPs, as well as their size and shape, are: fungal growth conditions, reagent concentration, reaction time, initial $\mathrm{pH}$, and temperature (Gemishev et al., 2019). Among the main NPs synthesized by Trichoderma are gold (AuNPs), ZnONPs, copper (CuNPs) and CuONPs, selenium (SeNPs), and AgNPs, which show different 


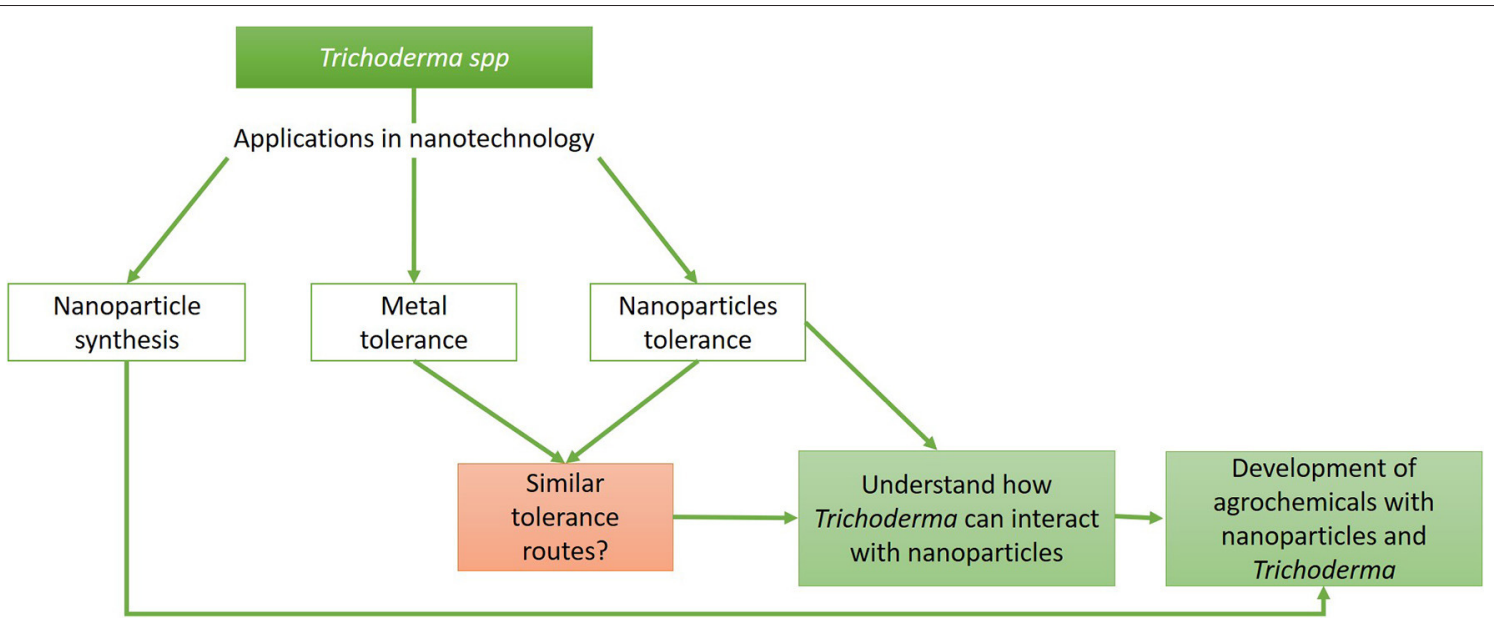

FIGURE 1 | Trichoderma and its relevance in nanotechnology. Flow chart representing the different areas where Trichoderma can be used in nanotechnology and how these can be united for the generation of products that improve agricultural crops.

characteristics and antimicrobial activities (Table 1). Some of the main NPs biosynthesized by Trichoderma and their mechanism of mycosynthesis are summarized below.

\section{Biosynthesis of AgNPs}

Silver NPs are of great interest due to their high bioactivity and broad antimicrobial spectrum, including plant pathogens (Tomah et al., 2020). Therefore, the use of AgNPs can improve the efficiency of agrochemicals as well as reduce the use of pesticides and biocides (Ahmed and Dutta, 2019).

Two mechanisms are used for the mycosynthesis of NPs: intracellular or extracellular, the extracellular method being the most used because it does not require the extraction of NPs from the cells. After all, only biomolecules secreted by the fungus catalyze a reduction of the metal precursor $\left(\mathrm{AgNO}_{3}\right.$ salt) generating AgNPs (Guilger-Casagrande and Lima, 2019). Moreover, mycosynthesis can be induced to obtain different characteristics of AgNPs that will depend on the fungal culture and production conditions (El-Moslamy et al., 2017).

It has been reported that the main enzymes involved in the biosynthesis of metal NPs in fungi are reductases (Vahabi and Dorcheh, 2014). Among this group of enzymes, nicotinamide adenine dinucleotide $(\mathrm{NADH})$-dependent nitrate reductase stands out, which is involved in the process of metal ion reduction (Gherbawy et al., 2013; Vahabi and Dorcheh, 2014; Guilger-Casagrande and Lima, 2019). For example, T. reesei produces extracellular enzymes that can reduce silver ions to AgNPs, with NADH-dependent nitrate reductase being the agent responsible for carrying out the reduction of $\mathrm{Ag}^{+}$metal ions into metal AgNPs (Gemishev et al., 2019). The reduction occurs due to the transfer of an electron from NADH with nitrate reductase acting as the electron carrier. Proteins can also bind to NPs and improve stability (Pal and Hossain, 2020). Furthermore, Vahabi and Dorcheh (2014) described that the reduction of silver to NPs is also possible by anthraquinones, naphthoquinones, and quinine derivatives, which can act as electron carriers in the reaction.

In the study by Saravanakumar et al. (2017), the authors reported that the size of the NPs varied according to the concentration of $\mathrm{AgNO}_{3}$, obtaining dispersed AgNPs, anisotropic in structure, and with an average size of $15-25 \mathrm{~nm}$. Gemishev et al. (2019), biosynthesized AgNPs extracellularly from an $\mathrm{AgNO}_{3}$ solution and used filtrates of $T$. reesei grown on different media. It was observed that the optimal medium contained $0.1 \%$ corn maceration liquor, $10 \%$ extracted biomass, and a concentration of $10 \mathrm{mM} \mathrm{AgNO} 3$ as a precursor, which produced non-toxic NPs with sizes between 15 and $25 \mathrm{~nm}$ in the crystalline phase, narrow size distribution, and improved stability among particles. On the other hand, in the study of Noshad et al. (2019), who applied an extract of Trichoderma harzianum to two different concentrations ( 1 and $2.5 \mathrm{mM}$ ) of $\mathrm{AgNO}_{3}$, AgNPs with sizes between 3 and $20 \mathrm{~nm}$ were generated. Furthermore, it was observed that the $1 \mathrm{mM}$ concentration produced AgNPs with a smaller size and better antimicrobial efficacy.

Sundaravadivelan and Padmanabhan (2014) obtained oval and monodisperse AgNPs with sizes between 10 and $20 \mathrm{~nm}$ by using the same concentration of $\mathrm{AgNO}_{3}$ and incubating for $24 \mathrm{~h}$. Interestingly, Shelar and Chavan (2015) worked with a $1 \mathrm{mM}$ concentration of $\mathrm{AgNO}_{3}$ and T. harzianum and obtained polydisperse, spherical, and ellipsoidal NPs with a size range of $19-63 \mathrm{~nm}$ at $3 \mathrm{~h}$ of exposure. The difference in the NP sizes reported in these two studies can probably be attributed to the variation in the exposure times to $\mathrm{AgNO}_{3}$ concentration.

Ramos et al. (2020), applied $\mathrm{pH}$ and reaction time variations for biosynthesis optimization using Trichoderma isolate TCH 01 and found that $\mathrm{pH} \mathrm{5,9}$ days of exposure, and $1 \mathrm{mM} \mathrm{AgNO}_{3}$ resulted in smaller sized NPs $(150 \mathrm{~nm})$ and better polydispersion rates. Similarly, Pal and Hossain (2020) sought to optimize the $\mathrm{pH}$, substrate concentration, and incubation period to obtain a better quality and quantity of AgNPs. Their results suggested that $\mathrm{pH} 9,72 \mathrm{~h}$ incubation period, and $2 \mathrm{mM} \mathrm{AgNO}_{3}$ were the optimal 
TABLE 1 | Nanoparticles (NPs) synthesized by Trichoderma.

\begin{tabular}{|c|c|c|c|c|c|}
\hline NPs & Strain & Size (nm) & Shape & Tested against & References \\
\hline \multirow[t]{13}{*}{$\mathrm{Ag}$} & T. asperellum & 4-14 Polydispersed & $\sim$ Spherical & No tested & Ahmed and Dutta, 2019 \\
\hline & T. atroviride & $10-15$ & Spherical & $\begin{array}{l}\text { Bacteria, Candida sp. and } \\
\text { Aspergillus sp., Fusarium } \\
\text { sp. }\end{array}$ & $\begin{array}{l}\text { Abdel-Kareem and Zohri, } \\
2018\end{array}$ \\
\hline & & $15-25$ & Anisotropic & $\begin{array}{l}\text { Escherichia coli, } \\
\text { Pseudomonas aeruginosa, } \\
\text { and Staphylococcus aureus }\end{array}$ & Saravanakumar et al., 2017 \\
\hline & $\begin{array}{l}\text { T. atroviride, } T \text {. atroviride, } T \text {. } \\
\text { afroharzianum, } T \text {. } \\
\text { brevicompactum, } T \text {. } \\
\text { dorothopsis, } T \text {. koningiopsis, } \\
\text { T. brevicompactum, } T \text {. } \\
\text { dorothopsis, } T \text {. citrinoviride, } \\
\text { T. asperellum, T. harzianum, } \\
\text { T. brevicompactum, } T \text {. } \\
\text { atroviride, } T \text {. virens, and T. } \\
\text { dorothopsis }\end{array}$ & $5-50$ & Spherical and oval & Sclerotinia sclerotiorum & Tomah et al., 2020 \\
\hline & T. harzianum & $\sim 50$ & Spherical and irregular & $\begin{array}{l}\text { S. aureus and Klebsiella } \\
\text { pneumonia }\end{array}$ & Ahluwalia et al., 2014 \\
\hline & & $5-18$ & Spherical & $\begin{array}{l}\text { Alternaria alternata, } \\
\text { Pyricularia oryzae, and S. } \\
\text { sclerotiorum }\end{array}$ & Consolo et al., 2020 \\
\hline & & 20-30 & Spherical & S. sclerotiorum & Guilger et al., 2017 \\
\hline & & 12.7 & Spherical & Not tested & El-Moslamy et al., 2017 \\
\hline & & $16-63$ & Spherical and ellipsoidal & Not tested & Shelar and Chavan, 2015 \\
\hline & & $3-20$ & Spherical & $\begin{array}{l}\text { Clavibacter michiganensis, } \\
\text { Streptococcus } \\
\text { thermophiles, and Bacillus } \\
\text { subtilis }\end{array}$ & Noshad et al., 2019 \\
\hline & & $10-20$ & Oval & Aedes aegypti & $\begin{array}{l}\text { Sundaravadivelan and } \\
\text { Padmanabhan, } 2014\end{array}$ \\
\hline & & $88-182$ & Spherical-Rod and Prism & S. sclerotiorum & $\begin{array}{l}\text { Guilger-Casagrande and } \\
\text { Lima, } 2019\end{array}$ \\
\hline & T. interfusant (FU21) & 59.66 & Spherical & Sclerotium rolfsii & Hirpara and Gajera, 2020 \\
\hline
\end{tabular}


TABLE 1 | Continued

\begin{tabular}{|c|c|c|c|c|c|}
\hline NPs & Strain & Size $(n m)$ & Shape & Tested against & References \\
\hline & T. logibrachiatum & 10 & Spherical & $\begin{array}{l}\text { Fusarium verticillioides, F. } \\
\text { moniliforme, Penicillium } \\
\text { brevicompactum, } \\
\text { Helminthosporium oryzae, } \\
\text { and Pyricylaria grisea }\end{array}$ & Elamawi et al., 2018 \\
\hline & & 61 & $\begin{array}{l}\text { Spherical, triangular, and } \\
\text { cuboid }\end{array}$ & $\begin{array}{l}\text { Halotolerant SRB mixed } \\
\text { culture }\end{array}$ & Omran et al., 2019 \\
\hline & T. reesei & $15-25$ & No specified & Not tested & Gemishev et al., 2019 \\
\hline & & $5-50$ & Variable & Not tested & Vahabi et al., 2011 \\
\hline & T. virens VN-11 & $8-60$ & Isotropic & No tested & Devi et al., 2013 \\
\hline & T. viride & $\begin{array}{l}\text { Not specified. } \\
\text { Polydispersed }\end{array}$ & Nanobowls & $\begin{array}{l}\text { B. subtilis and Klebsiella } \\
\text { planticola }\end{array}$ & Chitra and Annadurai, 2013 \\
\hline & & $1-50$ & Globular & $\begin{array}{l}\text { S. aureus, Shigella boydii, } \\
\text { Acinetobacter baumanni, } \\
\text { Shigella sonnei, and S. } \\
\text { typhimurium }\end{array}$ & Elgorban et al., 2016 \\
\hline & & $2-4$ & Spherical & No tested & Fayaz et al., 2010 \\
\hline & & $100-250$ & Spherical & $\begin{array}{l}\text { F. moliniforme and } \\
\text { Rhizoctonia solani }\end{array}$ & $\begin{array}{l}\text { Saravanakumar and Wang, } \\
\text { 2018; Manikandaselvi et al., } \\
2020\end{array}$ \\
\hline & $\begin{array}{l}\text { T. viride, T. hamatum, } T . \\
\text { harzianum, and T. koningii }\end{array}$ & $40-60$ & Spherical & $\begin{array}{l}\text { F. solani, Fusarium } \\
\text { semitectum, Fusarium } \\
\text { oxysporum, and Fusarium } \\
\text { roseum }\end{array}$ & El-Wakil, 2020 \\
\hline & Trichoderma koningii & $8-24$ & Spherical & Salmonella typhimurium & Tripathi et al., 2013 \\
\hline \multirow[t]{2}{*}{$\mathrm{ZnO}$} & T. harzianum & $134-200$ & Fan/bouquet structure & $\begin{array}{l}\text { A. alternata, P. oryzae, and } \\
\text { S. sclerotiorum }\end{array}$ & Consolo et al., 2020 \\
\hline & T. harzianum and T. reesei & $12-35$ & $\begin{array}{l}\text { Hexagonal wuetzite and } \\
\text { peaks }\end{array}$ & $\begin{array}{l}\text { Xanthomonas oryzae pv. } \\
\text { Oryzae }\end{array}$ & Shobha et al., 2020 \\
\hline \multirow[t]{3}{*}{$\mathrm{Au}$} & T. hamatumSU136 & $5-30$ & $\begin{array}{l}\text { Spherical, pentagonal, and } \\
\text { hexagonal }\end{array}$ & $\begin{array}{l}\text { B. subtilis ACCB 133, S. } \\
\text { aurous ACCB 136, P. } \\
\text { aeruginosa ACCB 156, and } \\
\text { Serratia sp. ACCB } 178\end{array}$ & $\begin{array}{l}\text { Abdel-Kareem and Zohri, } \\
2018\end{array}$ \\
\hline & T. harzianum & 30 & Spherical & No tested & do Nascimento et al., 2021 \\
\hline & & $26-34$ & Spherical & Not tasted & Tripathi et al., 2014 \\
\hline
\end{tabular}




\section{TABLE 1 | Continued}

\begin{tabular}{|c|c|c|c|c|c|}
\hline NPs & Strain & Size $(n m)$ & Shape & Tested against & References \\
\hline & & $26-34$ & Spherical & E. coli MTCC 1302 & Tripathi et al., 2018 \\
\hline & T. koningii & $5-40$ & $\begin{array}{l}\text { Small spheres to large } \\
\text { polygons (triangles and } \\
\text { hexagons) }\end{array}$ & No tested & Maliszewska et al., 2009 \\
\hline & T. longibrachiatum & 102.93-123.99 & Spherical and oval & $\begin{array}{l}\text { Aspergillus niger, A. flavus, } \\
\text { and A. fumigatus; E. coli, } \\
\text { Klebsiella granulomatis, } P \text {. } \\
\text { aeruginosa, and S. aureus }\end{array}$ & Elegbede et al., 2020 \\
\hline & T. viride & 59 & Spherical & $\begin{array}{l}\text { P. syringae, E. coli, Shigella } \\
\text { sonnei }\end{array}$ & Mishra et al., 2014 \\
\hline \multirow[t]{3}{*}{$\mathrm{Se}$} & T. harzianum JF309 & 60 & Irregular & Fusarium sp., Alternaria sp. & Hu et al., 2019 \\
\hline & $\begin{array}{l}\text { T. harzianum, } T \text {. atroviride, } T \text {. } \\
\text { virens, T. longibrechiatum, } \\
\text { and T. brevicompactum }\end{array}$ & $49.5-312.5$ & $\begin{array}{l}\text { Hexagonal, near spherical, } \\
\text { and irregular }\end{array}$ & Sclerospora graminicola & Nandini et al., 2017 \\
\hline & Trichoderma sp. WL-Go & 20-220 & $\begin{array}{l}\text { Spherical and } \\
\text { pseudo-spherical }\end{array}$ & Not tested & Diko et al., 2020 \\
\hline $\mathrm{Si}$ and $\mathrm{Cu}$ & T. atroviride & 55.5 (Si), $56(\mathrm{Cu})$ & Irregular spherical & $\begin{array}{l}\text { Poria hypolateritia and } \\
\text { Phomopsis theae }\end{array}$ & Natesan et al., 2021 \\
\hline $\mathrm{Au}$ and $\mathrm{Ag}$ & T. atroviride & $10-75$ & Triangular and spherical & P. theae & Ponmurugan, 2017 \\
\hline$\alpha-\mathrm{Fe}_{2} \mathrm{O}_{3}$ & T. harzianum & 207 & No specified & S. sclerotiorum & Bilesky-José et al., 2021 \\
\hline CdS & T. harzianum & $3-8$ & Spherical & No tested & Bhadwal et al., 2014 \\
\hline Chitosan & T. viride & 300 & Nearly spherical & $\begin{array}{l}\text { F. oxysporum, } R \text {. solani, and } \\
\text { S. rolfsii }\end{array}$ & Boruah and Dutta, 2021 \\
\hline $\mathrm{TiO}_{2}$ & T. viride & 74.4 & Spherical & Hecoverpa armigera & Chinnaperumal et al., 2018 \\
\hline \multirow[t]{2}{*}{$\mathrm{Cu}$} & T. koningiopsis & 87.5 & Spherical & Not tested & Salvadori et al., 2014a \\
\hline & T. asperellum & $10-190 \mathrm{~nm}$ & Spherical & Not tested & Saravanakumar et al., 2019 \\
\hline
\end{tabular}

The Trichoderma strain, type, size, and shape of the NPs are shown, as well as the organisms against they have been tested. 
conditions to obtain a spherical, monodisperse, and stable form of AgNPs. The optimal conditions discussed by the authors may diverge due to the existence of a dependence of the factors $(\mathrm{pH}$, incubation time, and $\mathrm{AgNO}_{3}$ concentration).

Regarding the optimal parameter settings for the mycosynthesis system, El-Moslamy et al. (2017), applied the Taguchi design using a T. harzianum strain. They succeeded in increasing the biomass yield in the production of AgNPs in the medium. The optimal conditions observed were as follows: a concentration of $\mathrm{AgNO}_{3}$ at $0.01 \mathrm{M}$, diluted reductant $(10 \mathrm{v} / \mathrm{v}, \mathrm{pH}$ 5), and incubation at $30^{\circ} \mathrm{C}, 200 \mathrm{rpm}$ for $24 \mathrm{~h}$.

Research in this regard has allowed the understanding of some important mechanisms that take place in mycosynthesis, which enables the optimization of the parameters used to generate specific characteristics in AgNPs, such as dispersion, stability, and biocompatibility. Altogether, these previous studies suggest that the characteristics of the obtained NPs depend on the fungi culture and the physicochemical conditions of production.

\section{Biosynthesis of SeNPs}

Selenium (Se) has beneficial effects at low concentrations on plant and animal metabolism, at the same time, it is involved in the protection against reactive oxygen species (ROS) in the form of selenoproteins (Bărbieru et al., 2019). Thus, SeNPs can be an alternative to the use of Se salts.

Regarding the synthesis of SeNPs, Hu et al. (2019) performed a comparison between a traditional synthesis (SNP, SeNPs) and biosynthesis (TSNP, SeNPs by Trichoderma) method of SeNPs. For biosynthesis, a concentration of $5 \mathrm{mM} \mathrm{NaSeO}_{3}$ was applied to a solution of metabolites of eight Trichoderma species. The results obtained with the SNP method were: SeNPs with spherical and pseudospherical shapes of $50 \mathrm{~nm}$, as well as the presence of polysaccharides. As for the SeNPs obtained by the TSNP method, they reported a size of $60 \mathrm{~nm}$ with an irregular shape, probably caused by the capping effect. At the same time, the study revealed an increase in the presence of amide materials in TSNP compared with SNP, which act as stabilizing agents (cappings). On the other hand, other studies such as that by Nandini et al. (2017), evaluated the production of SeNPs using three different media: culture filtrate $(\mathrm{CF})$, cell lysate $(\mathrm{CL})$, and crude cell wall (CW). They used six different species of Trichoderma spp. in each medium and applied a concentration of $25 \mathrm{mM} \mathrm{Na}_{2} \mathrm{SeO}_{3}$, obtaining SeNPs from 49.5 to $312.5 \mathrm{~nm}$ in all media. Based on the results, the best medium for NPs production was CF, as it facilitated the process compared with CL and CW. Other elements were also analyzed in mycosynthesis by Diko et al. (2020), who studied the effects of $\mathrm{pH}$ concerning inoculation time and $\mathrm{SeO}_{2}$ concentration. The optimal conditions $(\mathrm{pH}$ of $8,2 \mathrm{mM} \mathrm{SeO} 2$ concentration, $24 \mathrm{~h}$ of $\mathrm{SeO}_{2}$ inoculation, and Trichoderma sp.) produced spherical and pseudospherical SeNPs of 20-220 nm with the presence of alkene, alkane, and alcohol functional groups, thus suggesting their participation in the SeNPs synthesis reaction as cappings.

In contrast to the numerous studies on AgNPs, there is still little research on the synthesis of SeNPs. However, it can be suggested that SeNPs synthesized by Trichoderma have potential as an alternative to the use of Se salts and SeNPs originating from physical and chemical methods, since they present antioxidant and catalytic properties and can be used in biomedical, electronic, optical, and chemical fields.

\section{Biosynthesis of AuNPs}

Gold NPs can be used as catalysts, antimicrobial agents, or in the biomedical field as diagnostics, biomolecule detection, and nanodrug carriers (do Nascimento et al., 2021). For example, several studies have reported that AuNPs have antimicrobial activity against pathogens such as Aspergillus niger, Aspergillus flavus, Aspergillus fumigatus, Escherichia coli, Klebsiella granulomatis, Pseudomonas aeruginosa, Staphylococcus aureus, and Shigella sonnei (Mishra et al., 2014; Abdel-Kareem and Zohri, 2018; Tripathi et al., 2018; Elegbede et al., 2020). Moreover, the biosynthesis of AuNPs is presented as a low-cost and eco-friendly alternative for gold recovery, compared to electrochemical treatments of reverse osmosis and ion exchange resins (do Nascimento et al., 2021). In the study conducted by do do Nascimento et al. (2021), it was shown that T. harzianum has a gold biosorption capacity of $\sim 1,340 \mathrm{mg}$ of the metal per $\mathrm{g}$ of biomass in $180 \mathrm{~min}$, with a mycosynthesis of spherical NPs with a size below $30 \mathrm{~nm}$. Regarding the study of the optimal parameters for mycosynthesis, Abdel-Kareem and Zohri (2018) exposed T. hamatum SU136 to three different concentrations of $\mathrm{Au}_{2} \mathrm{Cl}_{6}(0.25,0.5$, and $1 \mathrm{mM})$. All conditions generated AuNPs, but the optimal parameters for obtaining smaller NPs were: $0.5 \mathrm{mM} \mathrm{Au} \mathrm{Cl}_{6}$ at $\mathrm{pH}$ of 7 and $38^{\circ} \mathrm{C}$. Similarly, Maliszewska et al. (2009) took concentration as the main variable, using the $\mathrm{HAuCl}_{4}$ solution. Their results suggested that the presence of free and exposed thiol (-SH) groups are essential for the reduction of gold ions. In the mycosynthesis performed by Tripathi et al. (2014), the authors contacted $5 \mathrm{~g}$ of wet biomass with $1 \mathrm{mM}$ $\mathrm{HAuCl}_{4}$ during a $72 \mathrm{~h}$ incubation period. The results showed a complete reduction of $\mathrm{Au}^{3+}$ into $\mathrm{Au}^{0}$ generating spherical NPs of $26-34 \mathrm{~nm}$. They observed that under metallic stress conditions $T$. harzianum synthesized cysteine extracellularly, which encapsulates the AuNPs to reduce the toxic effect of gold ions while stabilizing the NPs. Mishra et al. (2014), analyzed the effects of various other parameters such as temperature, $\mathrm{pH}$, cell extract concentration, and $\mathrm{HAuCl}_{4}$ concentration. The results showed that NPs were obtained at $\mathrm{pH} 7$ and 9 but not at a $\mathrm{pH}$ of 5; whereas for the temperatures analyzed $(20,30,40,40,50$, and $100^{\circ} \mathrm{C}$ ), it was found that the NPs are smaller than $20 \mathrm{~nm}$ in size at $100^{\circ} \mathrm{C}$; concerning the cell extract concentrations of Trichoderma viride cell extract concentrations studied (100, 50, and $10 \%)$, NPs were synthesized in less time at $10 \%$; finally, for the $\mathrm{HAuCl}_{4}$ concentrations (500 and $250 \mathrm{mg} / \mathrm{L}$ ), NPs were obtained after $10 \mathrm{~min}$ only at $250 \mathrm{mg} / \mathrm{L}$.

These studies indicate that the biosynthesis of AuNPs mediated by Trichoderma allows obtaining AuNPs with unique optical, thermal, chemical, and physical properties, which can also be used as a method for gold recovery.

\section{Biosynthesis of CuNPs and CuONPs}

Copper NPs have a wide number of applications, these can be used as high-temperature conductors, gas sensors, catalysts, in solar cells, and for wood treatment (Salvadori et al., 2014b). It 
has also been reported to exhibit antimicrobial activity against phytopathogens (Natesan et al., 2021). Their antimicrobial activity can be enhanced by their easy interaction with other particles, which is caused by the high surface-to-volume ratio (Al-Hakkani, 2020).

The amino and aromatic groups of secondary metabolites have been reported to act as encapsulants or reducing agents in the formation of CuONPs by T. asperellum (Saravanakumar et al., 2019). In the mycosynthesis of CuNPs performed by Salvadori et al. (2014b), they used the dead biomass of T. koningiopsis, because it presents a higher affinity to copper and adsorption capacity for metal ions $(21.1 \mathrm{mg} / \mathrm{g})$ when compared with live biomass and other biosorbents. The results obtained showed that $90 \%$ of the NPs were obtained in $60 \mathrm{~min}$, which was considered a fast process. The predominant shape of the CuNPs obtained by the authors was spherical with an average diameter of $87.5 \mathrm{~nm}$.

Little is known about this topic and it is necessary to generate a greater number of studies on the mycosynthesis of $\mathrm{Cu}$ and $\mathrm{CuONPs}$ for a better understanding of the mechanisms of action of the production, considering the potential application that these NPs present.

\section{Biosynthesis of ZnONPs}

Among the NPs that have been most widely used in agriculture, ZnONPs stand out as beneficial to plants and the soil microbiota (Shobha et al., 2020). Similarly, they possess antifungal activities against Fusarium spp., Botrytis cinerea, Penicillium expansum, A. niger, and Rhizhopus stolonifera. Similarly, ZnONPs are also considered effective antibacterial agents against a broad spectrum of species (Consolo et al., 2020). For example, Shobha et al. (2020) synthesized ZnONPs using three different Trichoderna isolates and tested their action against Xanthomonas oryzae pv. Oryzae. The ZnONPs they obtained presented unique shapes (hexagons and peaks) in the range of $12-35 \mathrm{~nm}$, which could be easily and sustainably produced on a large scale.

Previous research indicates that ZnONPs can be used as antimicrobials and as an alternative to chemical fertilizers in agriculture, being an environmentally friendly method of largescale production. However, more research is needed to fully decipher the best conditions to obtain NPs with the desired characteristics and to obtain better results when used in different areas, including agronanotechnology.

\section{EFFECT OF NPS IN TRICHODERMA}

The anthropogenic use of products containing different types of NPs is increasing, suggesting their imminent arrival in different ecosystems, including aquifers or agricultural soils. Some reports indicate that the presence of NPs can induce changes in microbial communities, even affecting the beneficial associations that these microorganisms can form with plants (Ameen et al., 2021). For example, Bandyopadhyay et al. (2012) analyzed the effect of ZnONPs on the nitrogen-fixing bacterium Sinorhizobium meliloti, a symbiotic bacterium associated with alfalfa, finding that they were highly toxic. Another study indicated that FeONPs at $3.2 \mathrm{mg} / \mathrm{kg}$ significantly reduced the mycorrhizal clover biomass by $34 \%$ by reducing the nutrient acquisition by the arbuscular mycorrhiza fungi (AMF) roots. In contrast, with AgNPs, no negative effects were observed at concentrations above 0.1 $\mathrm{mg} / \mathrm{kg}$; however, AgNPs at $0.01 \mathrm{mg} / \mathrm{kg}$ inhibited the growth of mycorrhizal clover (Feng et al., 2013). Cao et al. (2017), also worked with AgNPs and showed that there is an inhibition of the interaction of maize plants with arbuscular mycorrhizae, causing a significant decrease in root mycorrhizal colonization rate, soil alkaline phosphatase activity, available phosphorus (P) content, and plant $\mathrm{P}$ nutrition. These studies suggest that the effect that NPs will have on beneficial organisms and their associations with plants are highly varied, depending on the type of NPs, concentrations, and participating organisms.

So far, the study of the effect of NPs on fungi biocontrol is relatively new and there is limited information about it; however, studies on the effect of NPs on phytopathogenic fungi, such as Aspergillus, Fusarium, and Rhizopus, can provide information about their resistance mechanisms to propose possible strategies that can be presented in Trichoderma species giving them the advantage to tolerate higher concentrations of NPs than phytopathogens (Figure 2). The effects of different metal NPs on fungi that have been described are described below.

\section{Effect of SeNPs}

Selenium is a micronutrient that is incorporated into the structure of enzymes such as glutathione peroxidase, iodothyronine disiodase, and thioredoxin reductase, involved in the antioxidant response, detoxification processes, and cell growth, respectively (Forootanfar et al., 2014; Shakibaie et al., 2015). SeNPs have biomedical applications, such as treatments for cancer, diabetes, or inflammatory disorders, and have antioxidant, antimicrobial, and antiviral properties (Chen et al., 1992; Tseng, 2004; Messarah et al., 2012; Khurana et al., 2019).

Its antifungal effect was evaluated in $A$. niger, where at concentrations between 250 and $1,000 \mu \mathrm{g} / \mathrm{ml}$ diminished fungal growth; conversely, at subinhibitory concentrations $(10 \mu \mathrm{g} / \mathrm{ml})$ A. niger growth was stimulated, possibly since being a micronutrient, small concentrations of NPs can be used as cofactors by the enzymes mentioned above (Kazempour et al., 2013). In T. virens, the secretion of a thioredoxin reductase was reported during its interaction with maize plants (NogueiraLopez et al., 2018), suggesting that SeNPs could have an effect on the associations that Trichoderma has with plants. However, it is indispensable to further analyze whether this effect is positive or negative.

\section{Effect of AuNPs}

Gold NPs possess different physical and chemical properties that make them excellent structures for the fabrication of novel chemical and biological sensors. Moreover, they have applicability in different areas due to their optoelectronic properties, high biocompatibility, and antimicrobial activity (Das et al., 2011).

Studies have shown that AuNPs have an antifungal effect against $A$. niger and $A$. flavus, even better than commercial antifungal drugs (Jayaseelan et al., 2013). Interestingly, it is known that the antifungal effect of these NPs is enhanced when applied in conjunction with other materials such as 
chitosan, in addition to other factors such as the dose and concentration of the NPs. For example, the combination of these two nanomaterials is able to inhibit up to $100 \%$ of the growth of F. oxysporum when treated with doses up to $5 \mathrm{ml}$ with 25,50 , or $75 \mu \mathrm{g} / \mathrm{ml}$. These effects may be due to the fact that AuNPs have the ability to interact with enzymes involved in the regulation of the proton gradient to the extracellular medium, causing their inactivation, which would result in cell death (Lipşa et al., 2020).

In Trichoderma, its proton transport systems are efficient when facing different types of stress, managing to regulate $\mathrm{pH}$, and maintaining optimal growth (Ali and Hashem, 2007). Therefore, the mechanism of tolerance that Trichoderma could present against AuNPs would be a positive regulation in the synthesis of proton transporters, decreasing the imbalance of protons and leading to greater resistance to these compounds compared with phytopathogenic fungi.

\section{Effect of ZnONPs}

Zinc oxide NPs have been used as an antimicrobial agent due to their effectiveness, low cost, low toxicity to human cells, and stability (Sirelkhatim et al., 2015). In addition to that, their antifungal effects have been demonstrated against phytopathogenic fungi such as Fusarium graminearum and the biocontrol fungus $T$. viride. In the case of F. graminearum, there is evidence that the size of NPs is an important factor in the antifungal activity; for example, in a study by Dimkpa et al. (2013) where the antifungal effect of ZnONPs was compared with the zinc oxide micro-particles on F. graminearum, it was shown that ZnONPs exhibit a greater inhibition in fungal growth as opposed to zinc oxide micro-particles, this was due to the fact that NPs present a greater surface area compared with microparticles, which causes a greater interaction with the fungus. On the other hand, studies on $T$. viride show that the presence or absence of light is another factor to consider when working with ZnONPs. Luo and coworkers (2018), observed a higher percentage of inhibition by ZnONPs in the presence of light, reaching up to $99.26 \%$ compared with $8.15 \%$ shown in darkness. Similarly, it is shown that the capping of NPs presents an increase in the inhibition efficiency, mainly because capping reduces the aggregation of NPs by increasing the surface area, which generates a greater contact surface with compounds in the fungal cell wall, such as lipopolysaccharides, and exerting more intense stress than that generated by particles or zinc salts that have much larger sizes.

\section{Effect of AgNPs}

Due to their physicochemical and biological properties, AgNPs are widely used in various fields, such as sensors, antimicrobial agents, and catalysis (Zhang et al., 2014; Baghayeri et al., 2016; Saha et al., 2017).

Studies have shown that the use of AgNPs as antifungals reduces even by $90 \%$, the growth of some plant pathogens, such as Fusarium verticillioides, Fusarium moniliforme, Penicillium brevicompactum, Helminthosporium oryzae, and Pyricularia grisea (Elamawi et al., 2018). In Rhizopus sp. and Aspergillus sp., the AgNPs inhibited the hyphal growth, in addition to the detrimental effects on conidia germination and other deformations in the cell membrane structure and the inhibition of the normal development of both strains was observed (Medda et al., 2015).

The effect of these NPs is possibly due to the high affinity of AgNPs to interact and bind to external membrane proteins, affecting their integrity, forming ROS, and causing cell death (Ouda, 2014; Mahdizadeh et al., 2015; Medda et al., 2015; Elamawi et al., 2018). Another study reported that AgNPs almost completely inhibited the growth of Pythium aphanidermatum and Sclerotinia sclerotiurum, while T. harzianum had an inhibition percentage of about 80\% (Mahdizadeh et al., 2015). A possible mechanism explaining the higher tolerance of Trichoderma to AgNPs could be its ability to neutralize ROS by increasing the activity of antioxidant enzymes such as catalase and peroxidase, which have been shown to increase considerably in the presence of this type of stress, which could open the possibility of using these NPs in the control of phytopathogenic species without compromising the biocontrol fungal species.

\section{Effect of CuNPs and CuONPs}

Copper NPs have gained special attention in areas such as the agricultural industry because they have high selectivity against microorganisms at low concentrations, low toxicity to humans, and their production costs are lower compared with the synthesis of Ag and AuNPs (Pham et al., 2019; Maqsood et al., 2020).

The antifungal activity of CuNPs has been studied on Fusarium and Aspergillus, and it has been shown that the efficiency of the inhibition of fungal growth depends on factors such as concentration and NP size. Thus, when concentration is taken into account, Fusarium and Aspergillus growth inhibition percentages of up to 93.98 and $97 \%$ have been obtained at concentrations of 450 and 500 ppm, respectively (Viet et al., 2016; Pariona et al., 2019). On the other hand, when the size of the NPs is considered, it is possible to obtain a high inhibition percentage with much lower concentrations, as is shown in the study of Pham et al. (2019) who obtained an inhibition percentage of $72 \%$ at a concentration of $20 \mathrm{ppm}$ when the NPs are $53 \mathrm{~nm}$ in average size.

One of the reasons why fungal growth is inhibited by CuNPs is because they cause changes in morphology, ranging from deformations, rugosities, and weakening in the mycelium, or even non-germinated conidia, indicating a deleterious effect on the cell wall that leads to the expulsion of intracellular components and ultimately, cell death. These effects might possibly be due to disruption of the synthesis of cell wall compounds, such as chitin, causing a loss of cell wall stability and generating deformations and osmotic imbalances, thus facilitating the permeation of CuNPs (Pariona et al., 2019).

Banik and Luque (2017) showed that CuONPs did not affect the growth of T. harzianum at the presence of $200 \mathrm{mg} / \mathrm{mL}$ and only an effect in conidiation was observed. These results contrast with those observed in Phytophthora cinnamomi and Alternaria alternata, where the presence of 100 and $200 \mathrm{mg} / \mathrm{ml}$ of CuONPs, respectively, decreased the fungal growth rate.

It is well known that Trichoderma presents a defense response against ROS generated by the presence of metals or other NPs in the extracellular medium. Therefore, as with AgNPs, the increase 
in the enzymatic activity of catalase and peroxidase, responsible for neutralizing ROS, would be a mechanism of tolerance to CuNPs. Furthermore, considering how copper tolerance is conferred, another possibility is that the NPs accumulate in the Trichoderma cell wall, in the same way as it works with bulk copper. Therefore, if Trichoderma is able to tolerate higher concentrations of CuNPs compared with phytopathogenic fungi, it would be possible to apply it in the development of CuNPs products to minimize fungal diseases that might harm beneficial species.

\section{METAL TOLERANCE OF TRICHODERMA}

As mentioned above, there are few studies on the tolerance of Trichoderma to NPs, and trying to understand how Trichoderma can tolerate NPs, an analysis of metal tolerance may serve as a good approach. Below, we review the tolerance mechanisms that Trichoderma exhibits against metals (Table 2).

Studies on the tolerance and removal capacity of Trichoderma have been carried out under different conditions of $\mathrm{pH}$, temperature, and metal concentrations, with the aim of knowing the effects of changing these parameters in the characteristics of the NPs obtained and thus, how they can be used in different environments (Krantz-Rülcker et al., 1993; Ali and Hashem, 2007).

Several authors have suggested that the mechanisms responsible for metal tolerance are based on biosorption, as the metal is immobilized on the cell surface (adsorption) or accumulates inside the cell (absorption) (Errasquin and Vazquez, 2003; Kacprzak and Malina, 2005; Yazdani et al., 2010b; Chew et al., 2012; Hoseinzadeh et al., 2017; Zhang et al., 2020). However, the specific mechanism will depend on both the metal and fungal species under study (Errasquin and Vazquez, 2003; Ali and Hashem, 2007). In this section, the mechanisms of tolerance of Trichoderma to metals to which it can be commonly exposed in its natural habitat are presented (Figure 2).

\section{Tolerance to Lead}

Among the mechanisms that Trichoderma employs when is exposed to lead, it has been found that at high concentrations (up to $4,000 \mathrm{mg} / \mathrm{L}$ ), the fungus is capable of producing melanin in the chlamydospores to synthesize enzymes that allow it to immobilize lead through its transformation into less toxic species (Povedano-Priego et al., 2017). Similarly, it has been observed that when the $\mathrm{pH}$ of the medium changes, ion exchange takes place on the cell surface to maintain an equilibrium in the concentration of protons in the medium. In most cases, this process helps the $\mathrm{pH}$ value to approach 6 , where the highest removal efficiency is obtained (Ali and Hashem, 2007). These studies suggest that Trichoderma can be an excellent candidate for the removal of lead in the soil, based on the great quantities that it can tolerate and the fact that the $\mathrm{pH}$ present in agricultural soils is usually slightly acid.

\section{Tolerance to Cadmium}

Although cadmium is an uncommon element and has no known biological function, when introduced into the environment as waste, it can become one of the most toxic metals. In T. viride, the fungus can decrease its growth up to $97.2 \%$ under concentrations above $125 \mathrm{mg} / \mathrm{L}$ of cadmium (Errasquin and Vazquez, 2003; Zhang et al., 2020). On the other hand, it has been demonstrated that $\mathrm{pH}$ is a key factor in the tolerance to this metal since a better removal is observed at $\mathrm{pH} 4$, suggesting that a $\mathrm{pH}$ below neutrality supposes a positive effect in the tolerance to Trichoderma, similar to the tolerance to lead. This effect may be due to the fact that at slightly acidic $\mathrm{pH}$ values, the balance between the charges on the cell surface allows a better biosorption of metal ions to the binding sites.

The tolerance to this metal has also been studied from a metabolic point of view to know which processes are induced or repressed by this stress. It has been observed that cysteine metabolism may be involved in cadmium tolerance. For example, an increase in the enzymatic activity of O-acetyl-serine (thiol) lyase (OASTL) (enzyme responsible for the generation of cysteine from sulfur and O-acetyl-serine) occurs when Trichoderma is subjected to cadmium stress; in addition, a slight decrease in the cysteine concentration can also be observed, suggesting a relation between the cysteine metabolism and metal tolerance response in Trichoderma (Raspanti et al., 2009).

\section{Tolerance to Zinc}

Although zinc is an essential element for organisms, when it is present at high concentrations, it can become toxic. The tolerance to high concentrations of zinc by Trichoderma seems to be associated with the availability of carbon sources, it has been demonstrated that in a medium with saline solution, $T$. atroviride is able to remove up to 16 times more zinc than in a nutritive medium. Based on this, two mechanisms of response have been elucidated: the first is a process of active detoxification in the presence of a carbon source; the second is autolysis in the absence of the carbon source. The latter is the most efficient in removal because when the cell is ruptured, a larger surface area of the cell wall is exposed, thus increasing biosorption (Errasquin and Vazquez, 2003). This suggests that Trichoderma can be used under limiting concentrations of carbon sources to remove zinc.

\section{Tolerance to Copper}

Copper is the most common pollutant produced as waste from mining, metallurgy, fertilizer use, and the agro-industry, and is also a cofactor of several enzymes involved in different metabolic processes (Yazdani et al., 2010a). However, its excess within cells can cause the generation of ROS (Yazdani et al., 2009; Ayad et al., 2018).

As copper is a common contaminant, its concentrations in soils and water bodies are usually high and the tolerance of Trichoderma to this metal is good compared with that shown by other organisms. Tolerance up to $300 \mathrm{mg} / \mathrm{L}$ has been observed in both solid and liquid media, demonstrating that Trichoderma might be able to be used in bioremediation processes in the soil and water (Errasquin and Vazquez, 2003; Yazdani et al., 2010a; Yap et al., 2011; Maldaner et al., 2020). Anand et al. (2006) reported that $T$. viride is capable to tolerate copper up to a concentration of $200 \mathrm{mg} / \mathrm{L}$, with a limit at $300 \mathrm{mg} / \mathrm{L}$ of $\mathrm{Cu}(\mathrm{II})$ in which there was no growth. Moreover, T. viride bioaccumulates 


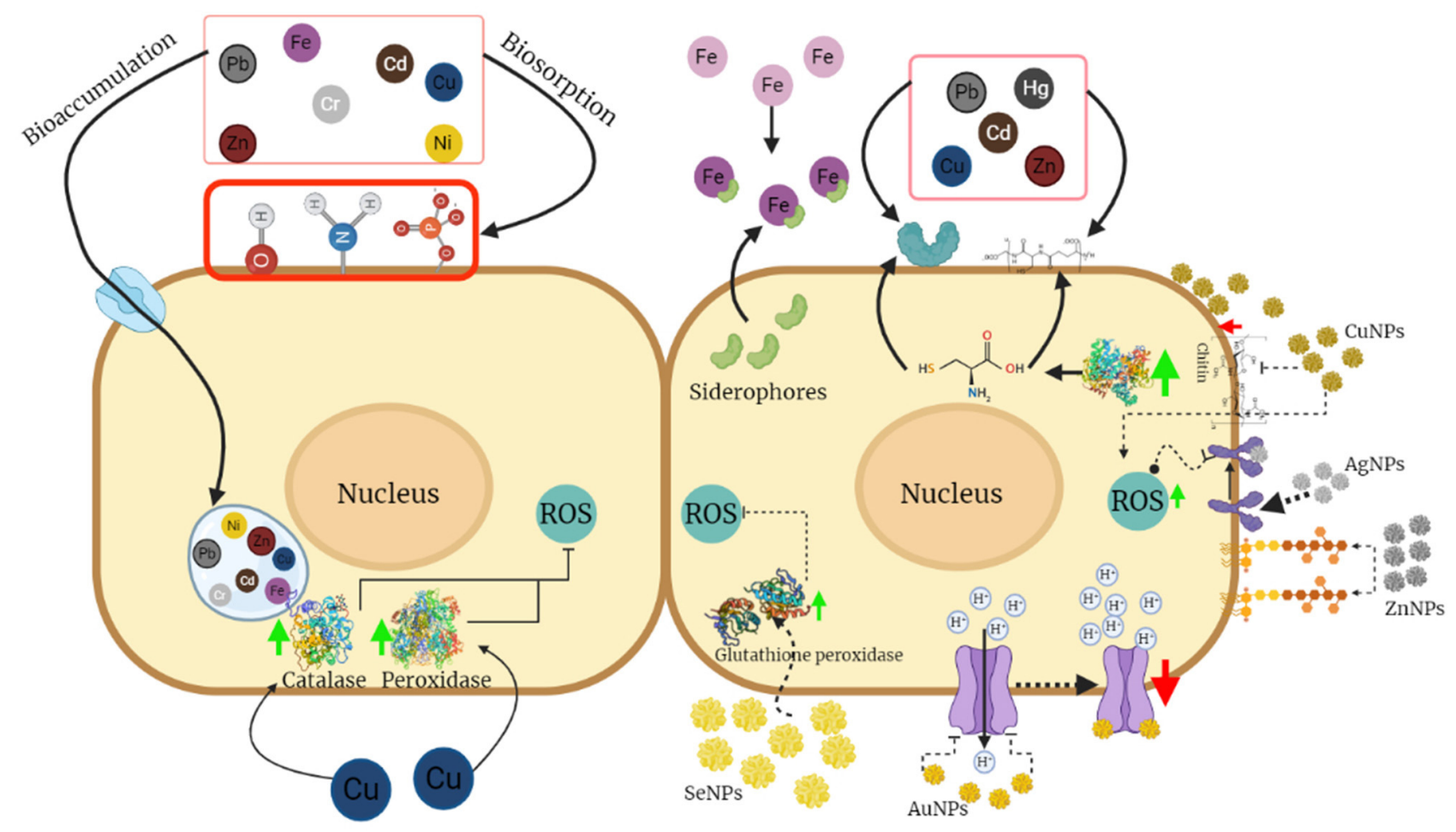

FIGURE 2 | Mechanisms of tolerance to metals and nanoparticles (NPs) in Trichoderma. Most of the mechanisms of tolerance to metals are based on processes of adsorption and absorption in the cell walls due to the presence of functional groups, proteins, or compounds that serve as chelating agents, as well as the accumulation of these in the vacuoles. Mechanisms involving the activity of antioxidant enzymes that reduce the damage caused by reactive oxygen species might also be present. This figure was created by BioRender.com.

copper as a layer on the cell wall surface as well. Another mechanism involved in copper tolerance showed that enzymes such as catalase and peroxidase increase their activity in the presence of copper, while the malondialdehyde (MDA) levels decrease (Juniors et al., 2020).

Therefore, it can be suggested that the tolerance that Trichoderma exhibits to copper are due to biosorption mechanisms where, on the one hand, copper can be absorbed on the cell surface by components that contain negatively charged groups in order to have an affinity for metal ions, or on the other hand, there can be a presence of copper transporting proteins that internalize it into the cell so that it can be used in metabolic processes or accumulated in the vacuole. The latter possibility would imply a highly strict transport regulation since high concentrations of copper inside the cell could cause cell death. In the case of the enzymatic activity of catalase and peroxidase, this could be considered a secondary tolerance mechanism that could act when the biosorption process is not sufficient. These studies suggest that Trichoderma has several mechanisms to efficiently tolerate the presence of copper, which represents an advantage in agriculture since several agrochemicals contain this metal in their formulation.

\section{Tolerance of Chromium}

Similar to cadmium, chromium is an extremely toxic element and, like copper, comes from metallurgical processes or the manufacture of batteries or wood preservation processes (Tumolo et al., 2020). Despite its high toxicity to biological systems, it has been found that Trichoderma species extracted from groundwater, have a great capacity to tolerate and remove this metal, showing removal efficiencies of up to 83.3\% (Chew et al., 2012). However, another study showed removal percentages of just $31.83 \%$ when using the species T. brevicompactum extracted from the earthworm intestine (Zhang et al., 2020). A possible explanation is that tolerance to these metals may vary according to the environment from which Trichoderma is isolated. For example, for species from groundwater, their environment may represent higher stress due to interactions with metals or toxic pollutants, compared with the strain obtained from earthworm gut.

These studies suggest that Trichoderma can tolerate large amounts of various metals that, due to anthropogenic activity, can be found in the soil and represent a danger to organisms present in this environment, including crops of agricultural importance. Moreover, this tolerance could be extrapolated to NPs that could be found in the environment where Trichoderma is present.

\section{CONCLUSIONS}

The presence of Trichoderma in the field has direct and indirect beneficial effects on commercial and food crops of interest 
TABLE 2 | Mechanisms of tolerance to metals in Trichoderma.

\begin{tabular}{|c|c|c|c|}
\hline Strain & Metal resistance & Mechanism & References \\
\hline \multirow[t]{2}{*}{ T. asperellum } & $\mathrm{Fe}, \mathrm{Cu}, \mathrm{Mn}$, and $\mathrm{Zn}$ & $\begin{array}{l}\text { Production of iron chelators } \\
\text { (siderophores) }\end{array}$ & de Santiago et al., 2011 \\
\hline & $\mathrm{Cu}$ & $\begin{array}{l}\text { Increase in catalase and } \\
\text { peroxidase activity }\end{array}$ & Juniors et al., 2020 \\
\hline \multirow[t]{3}{*}{ T. atroviride } & $\mathrm{Cu}, \mathrm{Cd}$, and $\mathrm{Zn}$ & $\begin{array}{l}\text { Biosorption by physical } \\
\text { binding to negatively } \\
\text { charged groups on the cell } \\
\text { wall }\end{array}$ & $\begin{array}{l}\text { Errasquin and Vazquez, } \\
2003\end{array}$ \\
\hline & $\mathrm{Zn}, \mathrm{Ba}$, and $\mathrm{Fe}$ & $\begin{array}{l}\text { Biosorption by functional } \\
\text { groups with metal } \\
\text { complexion capacity in the } \\
\text { cell wall }\end{array}$ & Kacprzak and Malina, 2005 \\
\hline & $\mathrm{Cu}$ & $\begin{array}{l}\text { Adsorption into the cell wall } \\
\text { and absorption }\end{array}$ & Yazdani et al., 2010a \\
\hline T. brevicompactum & $\mathrm{Cu}, \mathrm{Cr}, \mathrm{Cd}, \mathrm{Zn}$, and $\mathrm{Pb}$ & $\begin{array}{l}\text { Biosorption and } \\
\text { bioaccumulation by physical } \\
\text { binding to negatively } \\
\text { charged groups on the cell } \\
\text { wall }\end{array}$ & Zhang et al., 2020 \\
\hline \multirow[t]{2}{*}{ T. harzianum } & $\mathrm{Zn}, \mathrm{Pb}, \mathrm{Cd}$, and $\mathrm{Hg}$ & $\begin{array}{l}\text { Increase of OASTL activity } \\
\text { and transformation of } \\
\text { cysteine into chelators like } \\
\text { metallothioneins, } \\
\text { phytochelatins, etc. }\end{array}$ & Raspanti et al., 2009 \\
\hline & $\mathrm{Hg}$ & $\begin{array}{l}\text { Synthesis of hydrophobin by } \\
\text { up-regulation of the gene } \\
\text { encoding hydrophobin }\end{array}$ & Puglisi et al., 2012 \\
\hline T. viride & $\mathrm{Zn}(\mathrm{II}), \mathrm{Pb}(\mathrm{II})$, and $\mathrm{Cd}(\mathrm{II})$ & $\begin{array}{l}\text { lon exchange and } \\
\text { adsorption }\end{array}$ & Ali and Hashem, 2007 \\
\hline \multirow[t]{2}{*}{ Trichoderma sp. } & $\mathrm{Ni}, \mathrm{Cd}$, and $\mathrm{Cr}$ & $\begin{array}{l}\text { Adsorption and absorption } \\
\text { by functional groups }\end{array}$ & Chew et al., 2012 \\
\hline & $\mathrm{Pb}, \mathrm{Zn}, \mathrm{Cd}$, and $\mathrm{Cu}$ & $\begin{array}{l}\text { Intracellular accumulation } \\
\text { and melanin development }\end{array}$ & Ayad et al., 2018 \\
\hline T. asperelloides, T. hamatum, and T. harzianum & $\mathrm{Cd}, \mathrm{Cu}, \mathrm{Hg}$, and $\mathrm{Zn}$ & $\begin{array}{l}\text { Production of chelating } \\
\text { substances and proteins; } \\
\text { metal transport pathways } \\
\text { inside the cells }\end{array}$ & Maldaner et al., 2020 \\
\hline T. asperellum and T. harzianum & $\mathrm{Cd}, \mathrm{Pb}$, and $\mathrm{Ni}$ & $\begin{array}{l}\text { Biosorption by constituents } \\
\text { and functional groups on } \\
\text { the cell wall }\end{array}$ & Hoseinzadeh et al., 2017 \\
\hline
\end{tabular}

The strain of Trichoderma, the metal(s) to which it is tolerant, and the proposed mechanisms of tolerance are shown. 
in addition to its potential use in bioremediation and in the mycosynthesis of NPs. Few studies have been addressed the presence of metals and/or NPs in the field and their effect on Trichoderma and their beneficial associations, as well as on their mycoparasitic activity. Considering that an increasing number of products containing nanostructured compounds are reaching the field and consequently its eventual accumulation, they can affect the microorganisms and plants inhabiting these environments, including Trichoderma species. It is important to begin developing a greater number of investigations that allow us to know the specific effects whether positive or negative, that these nanostructured compounds have on the physiology, viability, and associations of Trichoderma. Although there will be variations depending on the nature of the nanoparticle, its shape, size, concentrations, as well as the species of Trichoderma and conditions tested, it is necessary to elucidate what phenotypes are at least expected in each condition to propose strategies for better use of these compounds and formulate an agrochemical that can affect different phytopathogens, but not Trichoderma. In this review, we focused on the effects in Trichoderma, but also, it is necessary to study if the presence of the NPs changes the capacity of the plant to establish specific plantfungus interactions.

In closing, Trichoderma emerges as a fungus capable of biosynthesizing NPs that can be used for the formulation of agrochemicals, as well as to treat pathogens not only of plants

\section{REFERENCES}

Abdel-Kareem, M. M., and Zohri, A. A. (2018). Extracellular mycosynthesis of gold nanoparticles using Trichoderma hamatum: optimization, characterization and antimicrobial activity. Lett. Appl. Microbiol. 67, 465-475. doi: 10.1111/lam.13055

Ahluwalia, V., Kumar, J., Sisodia, R., Shakil, N. A., and Walia, S. (2014). Green synthesis of silver nanoparticles by Trichoderma harzianum and their bioefficacy evaluation against Staphylococcus aureus and Klebsiella pneumonia. Industr. Crops Products 55, 202-206. doi: 10.1016/j.indcrop.2014.01. 026

Ahmed, A. A., and Dutta, P. (2019). Trichoderma asperellum mediated synthesis of silver nanoparticles: characterization and its physiological effects on tea [Camellia sinensis (L.) Kuntze var. assamica (J. Masters) Kitam.]. Int. J. Curr. Microbiol. App. Sci. 8, 1215-1229. doi: 10.20546/ijcmas.2019.804.140

Al-Hakkani, M. F. (2020). Biogenic copper nanoparticles and their applications: a review. SN Appl. Sci. 2, 1-20. doi: 10.1007/s42452-020-2279-1

Ali, E. H., and Hashem, M. (2007). Removal efficiency of the heavy metals $\mathrm{Zn}$ (II), $\mathrm{Pb}$ (II) and Cd (II) by Saprolegnia delica and Trichoderma viride at different $\mathrm{pH}$ values and temperature degrees. Mycobiology 35, 135-144. doi: 10.4489/MYCO.2007.35.3.135

Ameen, F., Alsamhary, K., Alabdullatif, J. A., and ALNadhari, S. (2021). A review on metal-based nanoparticles and their toxicity to beneficial soil bacteria and fungi. Ecotoxicol. Environ. Saf. 213:112027. doi: 10.1016/j.ecoenv.2021.112027

Anand, P., Isar, J., Saran, S., and Saxena, R. K. (2006). Bioaccumulation of copper by Trichoderma viride. Bioresour. Technol. 97, 1018-1025. doi: 10.1016/j.biortech.2005.04.046

Ayad, F., Matallah-Boutiba, A., Rouane-Hacene, O., Bouderbala, M., and Boutiba, Z. (2018). Tolerance of Trichoderma sp. to heavy metals and its antifungal activity in algerian marine environment. J. Marine Biol. Oceanogr. 7:2. doi: 10.22207/JPAM.12.2.48

Baghayeri, M., Tehrani, M. B., Amiri, A., Maleki, B., and Farhadi, S. (2016). A novel way for detection of antiparkinsonism drug entacapone via electrodeposition of silver nanoparticles/functionalized multi-walled carbon but also of other organisms, including human pathogens. It is a fungus easy to handle and with multiple physiological and technical advantages, and the fact that is used in nanotechnology as a new line of research suggests that there are still several mechanisms to be discovered, which makes this fungus a versatile tool for future biotechnology applications.

\section{AUTHOR CONTRIBUTIONS}

All authors listed contributed equally and they have made a substantial, direct, and intellectual contribution to the work and approved it for publication.

\section{FUNDING}

Research conducted and related to the topics of this review was supported by CONACyT grants CB 258569 and EcosNord 263456.

\section{ACKNOWLEDGMENTS}

We would like to thank Gustavo Caballero-Flores Ph.D. for his useful corrections and suggestions and Francisco Pérez and Yazmín Velázquez for their help to draw the figure and integrate the tables. nanotubes as an amperometric sensor. Mater. Sci. Eng. C 66, 77-83. doi: 10.1016/j.msec.2016.03.077

Bandyopadhyay, S., Peralta-Videa, J. R., Plascencia-Villa, G., José-Yacamán, M., and Gardea-Torresdey, J. L. (2012). Comparative toxicity assessment of $\mathrm{CeO}_{2}$ and $\mathrm{ZnO}$ nanoparticles towards Sinorhizobium meliloti, a symbiotic alfalfa associated bacterium: use of advanced microscopic and spectroscopic techniques. J. Hazard. Mater. 241, 379-386. doi: 10.1016/j.jhazmat.2012. 09.056

Banik, S., and Luque, A. P. (2017). In vitro effects of copper nanoparticles on plant pathogens, beneficial microbes and crop plants. Spanish J. Agric. Res. 15:23. doi: 10.5424/sjar/2017152-10305

Bărbieru, O. G., Dimitriu, L., Călin, M., Răut, I., Constantinescu-Aruxandei, D., and Oancea, F. (2019). Plant biostimulants based on selenium nanoparticles biosynthesized by Trichoderma strains. Multidiscipl. Digital Publish. Inst. Proc. 29:95. doi: 10.3390/proceedings2019029095

Bhadwal, A. S., Tripathi, R. M., Gupta, R. K., Kumar, N., Singh, R. P., and Shrivastav, A. (2014). Biogenic synthesis and photocatalytic activity of CdS nanoparticles. RSC Adv. 4, 9484-9490. doi: 10.1039/C3RA46221H

Bhainsa, K. C., and D'souza, S. F. (2006). Extracellular biosynthesis of silver nanoparticles using the fungus Aspergillus fumigatus. Colloids Surf. B Biointerfaces 47, 160-164. doi: 10.1016/j.colsurfb.2005.11.026

Bilesky-José, N., Maruyama, C., Germano-Costa, T., Campos, E., Carvalho, L., Grillo, R., et al. (2021). Biogenic $\alpha-\mathrm{Fe}_{2} \mathrm{O}_{3}$ nanoparticles enhance the biological activity of Trichoderma against the plant pathogen Sclerotinia sclerotiorum. ACS Sustain. Chem. Eng. 9, 1669-1683. doi: 10.1021/acssuschemeng.0c07349

Boruah, S., and Dutta, P. (2021). Fungus mediated biogenic synthesis and characterization of chitosan nanoparticles and its combine effect with Trichoderma asperellum against Fusarium oxysporum, Sclerotium rolfsii and Rhizoctonia solani. Indian Phytopathol. 74, 81-93. doi: 10.1007/s42360-020-00289-w

Cao, J., Feng, Y., He, S., and Lin, X. (2017). Silver nanoparticles deteriorate the mutual interaction between maize (Zea mays L.) and arbuscular mycorrhizal fungi: a soil microcosm study. Appl. Soil Ecol. 119, 307-316. doi: 10.1016/j.apsoil.2017.04.011 
Chen, C. J., Chen, C. W., Wu, M. M., and Kuo, T. L. (1992). Cancer potential in liver, lung, bladder and kidney due to ingested inorganic arsenic in drinking water. Br. J. Cancer 66, 888-892. doi: 10.1038/bjc.1992.380

Chew, A. W., Rahman, N. N., Kadir, M. O., and Chen, C. C. (2012). "Dried and wet Trichoderma sp. biomass adsorption capacity on $\mathrm{Ni}, \mathrm{Cd}$ and $\mathrm{Cr}$ in contaminated groundwater," in International Conference on Environmental Science and Technology (IPCBEE) (Singapore: IACSIT Press), 10-11.

Chinnaperumal, K., Govindasamy, B., Paramasivam, D., Dilipkumar, A., Dhayalan, A., Vadivel, A., and Pachiappan, P. (2018). Bio-pesticidal effects of Trichoderma viride formulated titanium dioxide nanoparticle and their physiological and biochemical changes on Helicoverpa armigera (Hub.). Pesticide Biochem. Physiol. 149, 26-36. doi: 10.1016/j.pestbp.2018.05.005

Chitra, K., and Annadurai, G. (2013). Bioengineered silver nanobowls using Trichoderma viride and its antibacterial activity against grampositive and gram-negative bacteria. J. Nanostruct. Chem. 3, 1-7. doi: 10.1186/2193-8865-3-9

Consolo, V. F., Torres-Nicolini, A., and Alvarez, V. A. (2020). Mycosinthetized Ag, $\mathrm{CuO}$ and $\mathrm{ZnO}$ nanoparticles from a promising Trichoderma harzianum strain and their antifungal potential against important phytopathogens. Sci. Rep. 10, 1-9. doi: 10.1038/s41598-020-77294-6

Contreras-Cornejo, H. A., Macías-Rodríguez, L., Cortés-Penagos, C., and López-Bucio, J. (2009). Trichoderma virens, a plant beneficial fungus, enhances biomass production and promotes lateral root growth through an auxin-dependent mechanism in Arabidopsis. Plant Physiol. 149, 1579-1592. doi: $10.1104 /$ pp.108.130369

Das, M., Shim, K. H., An, S. S. A., and Yi, D. K. (2011). Review on gold nanoparticles and their applications. Toxicol. Environ. Health Sci. 3, 193-205. doi: 10.1007/s13530-011-0109-y

de Santiago, A., Quintero, J. M., Avilés, M., and Delgado, A. (2011). Effect of Trichoderma asperellum strain T34 on iron, copper, manganese, and zinc uptake by wheat grown on a calcareous medium. Plant Soil 342, 97-104. doi: 10.1007/s11104-010-0670-1

Devi, T. P., Kulanthaivel, S., Kamil, D., Borah, J. L., Prabhakaran, N., and Srinivasa, N. (2013). Biosynthesis of Silver Nanoparticles from Trichoderma species.

Diko, C. S., Zhang, H., Lian, S., Fan, S., Li, Z., and Qu, Y. (2020). Optimal synthesis conditions and characterization of selenium nanoparticles in Trichoderma sp. WL-Go culture broth. Mater. Chem. Phys. 246:122583. doi: 10.1016/j.matchemphys.2019.122583

Dimkpa, C. O., McLean, J. E., Britt, D. W., and Anderson, A. J. (2013). Antifungal activity of $\mathrm{ZnO}$ nanoparticles and their interactive effect with a biocontrol bacterium on growth antagonism of the plant pathogen Fusarium graminearum. Biometals 26, 913-924. doi: 10.1007/s10534-013-96 67-6

do Nascimento, J. M., Cruz, N. D., de Oliveira, G. R., Sa, W. S., de Oliveira, J. D., Ribeiro, P. R. S., et al. (2021). Evaluation of the kinetics of gold biosorption processes and consequent biogenic synthesis of AuNPs mediated by the fungus Trichoderma harzianum. Environm. Technol. Innov. 21:101238. doi: 10.1016/j.eti.2020.101238

Elamawi, R. M., Al-Harbi, R. E., and Hendi, A. A. (2018). Biosynthesis and characterization of silver nanoparticles using Trichoderma longibrachiatum and their effect on phytopathogenic fungi. Egyptian J. Biol. Pest Control 28, 1-11. doi: 10.1186/s41938-018-0028-1

Elegbede, J. A., Lateef, A., Azeez, M. A., Asafa, T. B., Yekeen, T. A., Oladipo, I. C., et al. (2020). Biofabrication of gold nanoparticles using xylanases through valorization of corncob by Aspergillus niger and Trichoderma longibrachiatum: antimicrobial, antioxidant, anticoagulant and thrombolytic activities. Waste Biomass Valorization 11, 781-791. doi: 10.1007/s12649-018-0540-2

Elgorban, A. M., Al-Rahmah, A. N., Sayed, S. R., Hirad, A., Mostafa, A. A. F., and Bahkali, A. H. (2016). Antimicrobial activity and green synthesis of silver nanoparticles using Trichoderma viride. Biotechnol. Biotechnol. Equip. 30, 299-304. doi: 10.1080/13102818.2015.1133255

El-Moslamy, S. H., Elkady, M. F., Rezk, A. H., and Abdel-Fattah, Y. R. (2017). Applying Taguchi design and large-scale strategy for mycosynthesis of nanosilver from endophytic Trichoderma harzianum SYA. F4 and its application against phytopathogens. Sci. Rep. 7, 1-22. doi: 10.1038/srep45297

El-Wakil, D. A. (2020). Antifungal activity of silver nanoparticles by Trichoderma species: synthesis, characterization and biological evaluation. Egypt. J. Phytopathol. 48, 71-80. doi: 10.21608/ejp.2020.49395.1015
Errasquin, E. L., and Vazquez, C. (2003). Tolerance and uptake of heavy metals by Trichoderma atroviride isolated from sludge. Chemosphere 50, 137-143. doi: 10.1016/S0045-6535(02)00485-X

Fayaz, M., Tiwary, C. S., Kalaichelvan, P. T., and Venkatesan, R. (2010). Blue orange light emission from biogenic synthesized silver nanoparticles using Trichoderma viride. Colloids Surfaces B Biointerfaces 75, 175-178. doi: 10.1016/j.colsurfb.2009.08.028

Feng, Y., Cui, X., He, S., Dong, G., Chen, M., Wang, J., et al. (2013). The role of metal nanoparticles in influencing arbuscular mycorrhizal fungi effects on plant growth. Environ. Sci. Technol. 47, 9496-9504. doi: 10.1021/es402109n

Forootanfar, H., Adeli-Sardou, M., Nikkhoo, M., Mehrabani, M., Amir-Heidari, B., Shahverdi, A. R., et al. (2014). Antioxidant and cytotoxic effect of biologically synthesized selenium nanoparticles in comparison to selenium dioxide. J. Trace Elements Med. Biol. 28, 75-79. doi: 10.1016/j.jtemb.2013.07.005

Fraceto, L. F., Maruyama, C. R., Guilger, M., Mishra, S., Keswani, C., Singh, H. B., et al. (2018). Trichoderma harzianum-based novel formulations: potential applications for management of Next-Gen agricultural challenges. J. Chem. Technol. Biotechnol. 93, 2056-2063. doi: 10.1002/jctb.5613

Gemishev, O. T., Panayotova, M. I., Mintcheva, N. N., Djerahov, L. P., Tyuliev, G. T., and Gicheva, G. D. (2019). A green approach for silver nanoparticles preparation by cell-free extract from Trichoderma reesei fungi and their characterization. Mater. Res. Express 6:095040. doi: 10.1088/2053-1591/ab2e6a

Gherbawy, Y. A., Shalaby, I. M., El-sadek, M. S. A., Elhariry, H. M., and Banaja, A. A. (2013). The anti-fasciolasis properties of silver nanoparticles produced by Trichoderma harzianum and their improvement of the anti-fasciolasis drug triclabendazole. Int. J. Mol. Sci. 14, 21887-21898. doi: 10.3390/ijms141121887

Guilger, M., Pasquoto-Stigliani, T., Bilesky-Jose, N., Grillo, R., Abhilash, P. C., Fraceto, L. F., and De Lima, R. (2017). Biogenic silver nanoparticles based on Trichoderma harzianum: synthesis, characterization, toxicity evaluation and biological activity. Sci. Rep. 7, 1-13. doi: 10.1038/srep44421

Guilger-Casagrande, M., and Lima, R. D. (2019). Synthesis of silver nanoparticles mediated by fungi: a review. Front. Bioeng. Biotechnol. 7:287. doi: 10.3389/fbioe.2019.00287

Hermosa, R., Viterbo, A., Chet, I., and Monte, E. (2012). Plant-beneficial effects of Trichoderma and of its genes. Microbiology 158, 17-25. doi: 10.1099/mic.0.052274-0

Hirpara, D. G., and Gajera, H. P. (2020). Green synthesis and antifungal mechanism of silver nanoparticles derived from chitin?induced exometabolites of Trichoderma interfusant. Appl. Organ. Chem. 34:e5407. doi: 10.1002/aoc.5407

Honary, S., Barabadi, H., Gharaei-Fathabad, E., and Naghibi, F. (2012). Green synthesis of copper oxide nanoparticles using Penicillium aurantiogriseum, Penicillium citrinum and Penicillium waksmanii. Dig. J. Nanomater. Bios. 7, 999-1005.

Hoseinzadeh, S., Shahabivand, S., and Aliloo, A. A. (2017). Toxic metals accumulation in Trichoderma asperellum and T. harzianum. Microbiology 86, 728-736. doi: 10.1134/S0026261717060066

Hu, D., Yu, S., Yu, D., Liu, N., Tang, Y., Fan, Y., et al. (2019). Biogenic Trichoderma harzianum-derived selenium nanoparticles with control functionalities originating from diverse recognition metabolites against phytopathogens and mycotoxins. Food Control 106:106748. doi: 10.1016/j.foodcont.2019.106748

Jayaseelan, C., Ramkumar, R., Rahuman, A. A., and Perumal, P. (2013). Green synthesis of gold nanoparticles using seed aqueous extract of Abelmoschus esculentus and its antifungal activity. Ind. Crops Prod. 45, 423-429. doi: 10.1016/j.indcrop.2012.12.019

Juniors, P. T. E., Valeria, C. L., Santiago, P. O., Mario, R. M., and Gabriela, S. J. (2020). Tolerance to oxidative stress caused by copper (Cu) in Trichoderma asperellum To. Biocatal. Agric. Biotechnol. 29:101783. doi: 10.1016/j.bcab.2020.101783

Kacprzak, M., and Malina, G. (2005). The tolerance and $\mathrm{Zn}^{2+}, \mathrm{Ba}^{2+}$ and $\mathrm{Fe}^{3+}$ accumulation by Trichoderma atroviride and Mortierella exigua isolated from contaminated soil. Can. J. Soil Sci. 85, 283-290. doi: 10.4141/S04-018

Kareem, S. O., Adeleye, T. M., and Ojo, R. O. (2020). Effects of pH, temperature and agitation on the biosynthesis of iron nanoparticles produced by Trichoderma species. IOP Confer. Ser. Mater. Sci. Eng. 805:012036. doi: 10.1088/1757-899X/805/1/012036

Kazempour, Z. B., Yazdi, M. H., Rafii, F., and Shahverdi, A. R. (2013). Sub-inhibitory concentration of biogenic selenium nanoparticles lacks post 
antifungal effect for Aspergillus niger and Candida albicans and stimulates the growth of Aspergillus niger. Iran. J. Microbiol. 5:81.

Khurana, A., Tekula, S., Saifi, M. A., Venkatesh, P., and Godugu, C. (2019). Therapeutic applications of selenium nanoparticles. Biomed. Pharmacother. 111, 802-812. doi: 10.1016/j.biopha.2018.12.146

Krantz-Rülcker, C., Allard, B., and Schnürer, J. (1993). Interactions between a soil fungus, Trichoderma harzianum, and IIb metals-adsorption to mycelium and production of complexing metabolites. Biometals 6, 223-230. doi: 10.1007/BF00187759

Lipşa, F. D., Ursu, E. L., Ursu, C., Ulea, E., and Cazacu, A. (2020). Evaluation of the antifungal activity of gold-chitosan and carbon nanoparticles on Fusarium oxysporum. Agronomy 10:1143. doi: 10.3390/agronomy10081143

Luo, Z., Zhu, M., Guo, M., Lian, Z., Tong, W., Wang, J., et al. (2018). Ultrasonic-assisted dispersion of $\mathrm{ZnO}$ nanoparticles and its inhibition activity to Trichoderma viride. J. Nanosci. Nanotechnol. 18, 2352-2360. doi: 10.1166/jnn.2018.14397

Mahdizadeh, V., Safaie, N., and Khelghatibana, F. (2015). Evaluation of antifungal activity of silver nanoparticles against some phytopathogenic fungi and Trichoderma harzianum. J. Crop Prot. 4, 291-300.

Maldaner, J., Steffen, G. P. K., Saldanha, C. W., Steffen, R. B., Tabaldi, L. A., Missio, E. L., and Flores, R. (2020). Combining tolerant species and microorganisms for phytoremediation in aluminium-contaminated areas. Int. J. Environ. Stud. 77, 108-121. doi: 10.1080/00207233.2018.1560838

Maliszewska, I., Aniszkiewicz, L., and Sadowski, Z. (2009). Biological synthesis of gold nanostructures using the extract of Trichoderma koningii. Acta Phys. Polonica A 116, S163-165. doi: 10.12693/APhysPolA.116.S-163

Manikandaselvi, S., Sathya, V., Vadivel, V., Sampath, N., and Brindha, P. (2020). Evaluation of bio control potential of AgNPs synthesized from Trichoderma viride. Adv. Nat. Sci. 11:35004. doi: 10.1088/2043-6254/ab9d16

Maqsood, S., Qadir, S., Hussain, A., Asghar, A., Saleem, R., Zaheer, S., et al. (2020). Antifungal properties of copper nanoparticles against Aspergillus niger. Scholars Int. J. Biochem. 3, 87-91. doi: 10.36348/sijb.2020.v03i04.002

Medda, S., Hajra, A., Dey, U., Bose, P., and Mondal, N. K. (2015). Biosynthesis of silver nanoparticles from Aloe vera leaf extract and antifungal activity against Rhizopus sp. and Aspergillus sp. Appl. Nanosci. 5, 875-880. doi: 10.1007/s13204-014-0387-1

Messarah, M., Klibet, F., Boumendjel, A., Abdennour, C., Bouzerna, N., Boulakoud, M. S., et al. (2012). Hepatoprotective role and antioxidant capacity of selenium on arsenic-induced liver injury in rats. Exp. Toxicol. Pathol. 64, 167-174. doi: 10.1016/j.etp.2010.08.002

Mishra, A., Kumari, M., Pandey, S., Chaudhry, V., Gupta, K. C., and Nautiyal, C. S. (2014). Biocatalytic and antimicrobial activities of gold nanoparticles synthesized by Trichoderma sp. Bioresour. Technol. 166, 235-242. doi: 10.1016/j.biortech.2014.04.085

Nandini, B., Hariprasad, P., Prakash, H. S., Shetty, H. S., and Geetha, N. (2017). Trichogenic-selenium nanoparticles enhance disease suppressive ability of Trichoderma against downy mildew disease caused by Sclerospora graminicola in pearl millet. Sci. Rep. 7, 1-11. doi: 10.1038/s41598-017-0 $2737-6$

Narayanan, K. B., and Sakthivel, N. (2010). Biological synthesis of metal nanoparticles by microbes. Adv. Colloid Interface Sci. 156, 1-13. doi: $10.1016 /$ j.cis.2010.02.001

Natesan, K., Ponmurugan, P., Gnanamangai, B. M., Manigandan, V., Joy, S. P. J., Jayakumar, C., et al. (2021). Biosynthesis of silica and copper nanoparticles from Trichoderma, Streptomyces and Pseudomonas spp. evaluated against collar canker and red root-rot disease of tea plants. Arch. Phytopathol. Plant Protect. 54, 56-85. doi: 10.1080/03235408.2020. 1817258

Nogueira-Lopez, G., Greenwood, D. R., Middleditch, M., Winefield, C., Eaton, C., Steyaert, J. M., et al. (2018). The apoplastic secretome of Trichoderma virens during interaction with maize roots shows an inhibition of plant defence and scavenging oxidative stress secreted proteins. Front. Plant Sci. 9:409. doi: 10.3389 /fpls.2018.00409

Noshad, A., Iqbal, M., Folkers, L., Hetherington, C., Khan, A., Numan, M., et al. (2019). Antibacterial effect of silver nanoparticles (AgNPs) synthesized from Trichoderma harzianum against Clavibacter michiganensis. J. Nano Res. 58, 10-19. doi: 10.4028/www.scientific.net/JNanoR.58.10
Omran, B. A., Nassar, H. N., Younis, S. A., Fatthallah, N. A., Hamdy, A., ElShatoury, E. H., and El-Gendy, N. S. (2019). Physiochemical properties of Trichoderma longibrachiatum DSMZ 16517-synthesized silver nanoparticles for the mitigation of halotolerant sulphate-reducing bacteria. J. Appl. Microbiol. 126, 138-154. doi: 10.1111/jam.14102

Ouda, S. M. (2014). Antifungal activity of silver and copper nanoparticles on two plant pathogens, Alternaria alternata and Botrytis cinerea. Res. J. Microbiol. 9:34. doi: $10.3923 / \mathrm{jm} .2014 .34 .42$

Pal, S., and Hossain, K. S. (2020). Optimization of mycobiosynthesis of silver nanoparticles by using Fusarium 4F1 and Trichoderma TRS isolates. Bangladesh J. Botany 49, 343-348. doi: 10.3329/bjb.v49i2.49315

Pariona, N., Mtz-Enriquez, A. I., Sánchez-Rangel, D., Carrión, G., ParaguayDelgado, F., and Rosas-Saito, G. (2019). Green-synthesized copper nanoparticles as a potential antifungal against plant pathogens. RSC Adv. 9, 18835-18843. doi: 10.1039/C9RA03110C

Pham, N. D., Duong, M. M., Le, M. V., and Hoang, H. A. (2019). Preparation and characterization of antifungal colloidal copper nanoparticles and their antifungal activity against Fusarium oxysporum and Phytophthora capsici. Comptes Rendus Chimie 22, 786-793. doi: 10.1016/j.crci.2019.10.007

Ponmurugan, P. (2017). Biosynthesis of silver and gold nanoparticles using Trichoderma atroviride for the biological control of Phomopsis canker disease in tea plants. IET Nanobiotechnol. 11, 261-267.

Povedano-Priego, C., Martín-Sánchez, I., Jroundi, F., Sánchez-Castro, I., and Merroun, M. L. (2017). Fungal biomineralization of lead phosphates on the surface of lead metal. Miner. Eng. 106, 46-54. doi: 10.1016/j.mineng.2016.11.007

Puglisi, I., Faedda, R., Sanzaro, V., Piero, A. R. L., Petrone, G., and Cacciola, S. O. (2012). Identification of differentially expressed genes in response to mercury I and II stress in Trichoderma harzianum. Gene 506, 325-330. doi: 10.1016/j.gene.2012.06.091

Rai, M., Bonde, S., Golinska, P., Trzcińska-Wencel, J., Gade, A., Abd-Elsalam, K., et al. (2021). Fusarium as a novel fungus for the synthesis of nanoparticles: mechanism and applications. J. Fungi 7:139. doi: 10.3390/jof7020139

Ramos, M. M., Morais, E. D. S., Sena, I. D. S., Lima, A. L., de Oliveira, F. R., de Freitas, C. M., et al. (2020). Silver nanoparticle from whole cells of the fungi Trichoderma spp. isolated from Brazilian Amazon. Biotechnol. Lett. 42, 833-843. doi: 10.1007/s10529-020-02819-y

Raspanti, E., Cacciola, S. O., Gotor, C., Romero, L. C., and García, I. (2009). Implications of cysteine metabolism in the heavy metal response in Trichoderma harzianum and in three Fusarium species. Chemosphere 76, 48-54. doi: 10.1016/j.chemosphere.2009.02.030

Saha, J., Begum, A., Mukherjee, A., and Kumar, S. (2017). A novel green synthesis of silver nanoparticles and their catalytic action in reduction of Methylene Blue dye. Sustain. Environ. Res. 27, 245-250. doi: 10.1016/j.serj.2017.04.003

Salvadori, M. R., Ando, R. A., Oller Do Nascimento, C. A., and Correa, B. (2014a). Bioremediation from wastewater and extracellular synthesis of copper nanoparticles by the fungus Trichoderma koningiopsis. J. Environ. Sci. Health Part A 49, 1286-1295. doi: 10.1080/10934529.2014.910067

Salvadori, M. R., Ando, R. A., Oller do Nascimento, C. A., and Corrêa, B. (2014b). Intracellular biosynthesis and removal of copper nanoparticles by dead biomass of yeast isolated from the wastewater of a mine in the Brazilian Amazonia. PLoS ONE 9:e87968. doi: 10.1371/journal.pone.0087968

Saravanakumar, K., Li, Y., Yu, C., Wang, Q. Q., Wang, M., Sun, J., et al. (2017). Effect of Trichoderma harzianum on maize rhizosphere microbiome and biocontrol of Fusarium Stalk rot. Sci. Rep. 7, 1-13. doi: 10.1038/s41598-017-01680-w

Saravanakumar, K., Shanmugam, S., Varukattu, N. B., MubarakAli, D., Kathiresan, K., and Wang, M. H. (2019). Biosynthesis and characterization of copper oxide nanoparticles from indigenous fungi and its effect of photothermolysis on human lung carcinoma. J. Photochem. Photobiol. B Biol. 190, 103-109. doi: 10.1016/j.jphotobiol.2018.11.017

Saravanakumar, K., and Wang, M. H. (2018). Trichoderma based synthesis of anti-pathogenic silver nanoparticles and their characterization, antioxidant and cytotoxicity properties. Microb. Pathog. 114, 269-273. doi: 10.1016/j.micpath.2017.12.005

Shakibaie, M., Mohazab, N. S., and Mousavi, S. A. A. (2015). Antifungal activity of selenium nanoparticles synthesized by Bacillus species Msh-1 against 
Aspergillus fumigatus and Candida albicans. Jundishapur J. Microbiol. 8, 1-4. doi: $10.5812 /$ jjm. 26381

Shelar, G. B., and Chavan, A. M. (2015). Myco-synthesis of silver nanoparticles from Trichoderma harzianum and its impact on germination status of oil seed. Biolife 3, 109-113.

Shobha, B., Lakshmeesha, T. R., Ansari, M. A., Almatroudi, A., Alzohairy, M. A., Basavaraju, S., et al. (2020). Mycosynthesis of $\mathrm{ZnO}$ nanoparticles using Trichoderma spp. isolated from rhizosphere soils and its synergistic antibacterial effect against Xanthomonas oryzae pv. oryzae. J. Fungi 6:181. doi: $10.3390 /$ jof 6030181

Singh, R. P., Handa, R., and Manchanda, G. (2020). Nanoparticles in sustainable agriculture: an emerging opportunity. J. Controlled Release 329, 1234-1248. doi: 10.1016/j.jconrel.2020.10.051

Sirelkhatim, A., Mahmud, S., Seeni, A., Kaus, N. H. M., Ann, L. C., Bakhori, S. K. M., et al. (2015). Review on zinc oxide nanoparticles: antibacterial activity and toxicity mechanism. Nano-micro Lett. 7, 219-242. doi: $10.1007 / \mathrm{s} 40820-015-0040-\mathrm{x}$

Sundaravadivelan, C., and Padmanabhan, M. N. (2014). Effect of mycosynthesized silver nanoparticles from filtrate of Trichoderma harzianum against larvae and pupa of dengue vector Aedes aegypti L. Environ. Sci. Pollut. Res. 21, 4624-4633. doi: 10.1007/s11356-013-2358-6

Tomah, A. A., Alamer, I. S. A., Li, B., and Zhang, J. Z. (2020). Mycosynthesis of silver nanoparticles using screened Trichoderma isolates and their antifungal activity against Sclerotinia sclerotiorum. Nanomaterials 10:1955. doi: 10.3390/nano10101955

Tripathi, P., Singh, P. C., Mishra, A., Chauhan, P. S., Dwivedi, S., Bais, R. T., et al. (2013). Trichoderma: a potential bioremediator for environmental cleanup. Clean Technol. Environ. Policy 15, 541-550. doi: 10.1007/s10098-012-0553-7

Tripathi, R. M., Gupta, R. K., Singh, P., Bhadwal, A. S., Shrivastav, A., Kumar, N., and Shrivastav, B. R. (2014). Ultra-sensitive detection of mercury (II) ions in water sample using gold nanoparticles synthesized by Trichoderma harzianum and their mechanistic approach. Sens. Actuat Chem. 204, 637-646. doi: 10.1016/j.snb.2014.08.015

Tripathi, R. M., Shrivastav, B. R., and Shrivastav, A. (2018). Antibacterial and catalytic activity of biogenic gold nanoparticles synthesised by Trichoderma harzianum. IET Nanobiotechnol. 12, 509-513.

Tseng, C. H. (2004). The potential biological mechanisms of arsenicinduced diabetes mellitus. Toxicol. Appl. Pharmacol. 197, 67-83. doi: $10.1016 /$ j.taap.2004.02.009

Tumolo, M., Ancona, V., De Paola, D., Losacco, D., Campanale, C., Massarelli, C., et al. (2020). Chromium pollution in European water, sources, health risk, and remediation strategies: an overview. Int. J. Environ. Res. Public Health 17:5438. doi: 10.3390/ijerph17155438

Vahabi, K., and Dorcheh, S. K. (2014). "Biosynthesis of silver nano-particles by
Trichoderma and its medical applications," in Biotechnology and Biology of Trichoderma (Oxford: Elsevier), 393-404.

Vahabi, K., Mansoori, G. A., and Karimi, S. (2011). Biosynthesis of silver nanoparticles by fungus Trichoderma reesei (a route for large-scale production of AgNPs). Insciences J. 1, 65-79. doi: 10.5640/insc.010165

Viet, P. V., Nguyen, H. T., Cao, T. M., and Hieu, L. V. (2016). Fusarium antifungal activities of copper nanoparticles synthesized by a chemical reduction method. J. Nanomater. 1-7. doi: 10.1155/2016/1957612

Yap, C. K., Yazdani, M., Abdullah, F., and Tan, S. G. (2011). Is the high Cu tolerance of Trichoderma atroviride isolated from the $\mathrm{Cu}$-polluted sediment due to adaptation? An in vitro toxicological study. Sains Malaysiana 40, 119-124.

Yazdani, M., Yap, C. K., Abdullah, F., and Tan, S. G. (2009). Trichoderma atroviride as a bioremediator of $\mathrm{Cu}$ pollution: an in vitro study. Toxicol. Environ. Chem. 91, 1305-1314. doi: 10.1080/02772240802616510

Yazdani, M., Yap, C. K., Abdullah, F., and Tan, S. G. (2010b). An in vitro study on the adsorption, absorption and uptake capacity of $\mathrm{Zn}$ by the bioremediator Trichoderma atroviride. Environ. Asia 3, 53-59.

Yazdani, M., Yap, C. K., and Abdullah, F. (2010a). Adsorption and absorption of $\mathrm{Cu}$ in Trichoderma atroviride. Pertanika J. Trop. Agric. Sci. 33, 71-77.

Zhang, D., Yin, C., Abbas, N., Mao, Z., and Zhang, Y. (2020). Multiple heavy metal tolerance and removal by an earthworm gut fungus Trichoderma brevicompactum QYCD-6. Sci. Rep. 10, 1-9. doi: 10.1038/s41598-02063813-y

Zhang, T., Wang, L., Chen, Q., and Chen, C. (2014). Cytotoxic potential of silver nanoparticles. Yonsei Med. J. 55, 283-291. doi: 10.3349/ymj.2014.55.2.283

Conflict of Interest: The authors declare that the research was conducted in the absence of any commercial or financial relationships that could be construed as a potential conflict of interest.

Publisher's Note: All claims expressed in this article are solely those of the authors and do not necessarily represent those of their affiliated organizations, or those of the publisher, the editors and the reviewers. Any product that may be evaluated in this article, or claim that may be made by its manufacturer, is not guaranteed or endorsed by the publisher.

Copyright $\odot 2021$ Ramírez-Valdespino and Orrantia-Borunda. This is an openaccess article distributed under the terms of the Creative Commons Attribution License (CC BY). The use, distribution or reproduction in other forums is permitted, provided the original author $(s)$ and the copyright owner(s) are credited and that the original publication in this journal is cited, in accordance with accepted academic practice. No use, distribution or reproduction is permitted which does not comply with these terms. 